\title{
PENGARUH PENGGUNAAN LKS EKSPLORATIF BERKONTEKS BUDAYA BANTEN TERHADAP KEMAMPUAN PEMAHAMAN KONSEP MATEMATIS DI SEKOLAH DASAR
}

\author{
Melia Livita Elvara', Sukirwan², Aan Subhan Pamungkas ${ }^{3}$ \\ ${ }^{123}$ FKIP, Universitas Sultan Ageng Tirtayasa, Jl. Raya Jakarta Km. 4 Pakupatan, Kota Serang, Banten \\ melialivitaelvara@gmail.com
}

\begin{abstract}
The research aims to determine the influence of application explorative worksheet on matematical ability of concepts understanding of grade fifth Elementary School students. The type of this research is quasi experiment with quantitative approach and using non-equivalent control group design. The subject on this research is students on fifth grade Sempu 2 Elementary School. The sample of this research consist of two class, control class and experiment class. Treatment was carried on experiment class by using explorative student worksheet with curtural context in Banten. The result of this research indicated that application explorative student worksheet with cultural context in Banten makes matematical ability of concept understanding be better. The posttest mean values on experiment class was 87,6 that be better of control class was 76,7 . The response of the students who were taught by using explorative worksheet with cultural context in Banten was 93,2 percents with a very good category. Teh two tail of t-test with $\alpha=0,05$ and $\mathrm{dk}=\mathrm{n}_{1}+\mathrm{n}_{2}-2$, obtained $\mathrm{t}_{\text {count }} 0,37<\mathrm{t}_{\text {table }} 2,60$, the one tail posttest of t-test obtained $t_{\text {count }} 3,79>t_{\text {table }} 2,50$. The results of this indicated that there were differences on the students ability in the mathematical ability of concepts understanding of the experimental class with the control class and the students in mathematical ability of concepts understanding of the experimental class was better than the control class.
\end{abstract}

Keywords: Banten Culture, Matematical Ability of Understanding Concepts, Explorative Student Worksheet

\begin{abstract}
ABSTRAK
Penelitian ini bertujuan untuk mengetahui pengaruh penggunaan LKS eksploratif terhadap kemampuan pemahaman konsep matematis siswa SD kelas V. Jenis penelitian ini adalah penelitian quasi eksperimen dengan pendekatan kuantitatif dan menggunakan desain penelitian non-equivalent control group design. Subjek penelitian ini adalah siswa kelas V SDN Sempu 2. Sampel penelitian ini terdiri dari dua kelas, kelas kontrol dan kelas eksperimen. Perlakuan yang diberikan pada kelas ekperimen dengan menggunakan LKS eksploratif berkonteks budaya Banten. Hasil penelitian ini menunjukkan bahwa penggunaan LKS eksploratif berkonteks budaya Banten membuat kemampuan pemahaman konsep matematis siswa menjadi lebih baik. Nilai rata-rata posttes siswa kelas eksperimen 87,6 lebih baik dari pada siswa kelas kontrol 76,7. Respon siswa pengguna LKS eksploratif berkonteks budaya Banten sebesar 93,2 \% dengan kriteria sangat baik. Uji-t dua pihak pretest dengan $\alpha=0,05$ dengan $\mathrm{dk}=\mathrm{n}_{1}+\mathrm{n}_{2}-2$, diperoleh $t_{\text {hitung }} 0,37<t_{\text {tabel }} 2,60$, uji satu pihak posttest $t_{\text {hitung }} 3,79>$ $t_{\text {tabel }} 2$ 2,50. Hasil tersebut menujukkan bahwa terdapat perbedaan kemampuan pemahaman konsep matematis siswa kelas eksperimen dan kelas kontrol serta kemampuan pemahaman konsep matematis siswa kelas eksperimen lebih baik dari pada kelas kontrol.
\end{abstract}

Katakunci: Budaya Banten, Kemampuan Pemahaman Konsep Matematis, LKS Eksploratif

\section{PENDAHULUAN}

Pendidikan merupakan proses meningkatkan tarap kemahiran seseorang dalam hal wawasan ilmu pengetahuan serta perkembangan sikap atau moral sehingga mampu melaksanakan hak dan kewajiban nya sebagai manusia seutuhnya. Seiring berkembangnya zaman, tantangan pendidikan abad 21 semakin berat terutama dalam hal globalisasi serta kecanggihan teknologi. Selain tantangan 
globalisasi, dan perkembangan iptek, tantangan kebudayaan manusia Indonesia juga sangat penting untuk diperhatikan dalam pendidikan. Pendidikan dapat diartikan sebagai kegiatan transformasi/ pewarisan budaya dari satu generasi ke generasi berikutnya. Oleh karenanya, landasan kultural/ budaya menjadi penting dalam penyelenggaraan pendidikan. Menurut Koentjaraningrat (Titarahardja \& Sulo, 2013) dalam arti luas budaya dapat berwujud; a) ide, gagasan, dan nilai, b) kelakuan berpola dari manusia dalam masyarakat, c) fisik yakni benda hasil karya manusia. Selain itu, budaya juga mencakup unsur-unsur mulai dari sistem religi, kemasyarakatan, pengetahuan, bahasa, kesenian, mata pencaharian, sampai dengan sistem teknologi dan peralatan (Titarahardja \& Sulo, 2013). Dalam konteks wilayah provinsi Banten, pendidikan yang terselenggara seyogyanya mentransformasikan unsur-unsur budaya tersebut dalam proses pembelajaran baik melalui media, bahan ajar, maupun alat bantu belajar seperti LKS.

Penyelenggaraan pendidikan di Indonesia diatur dalam UU No. 20 Tahun 2003 Tentang Sisdiknas. Penyelenggaraan pendidikan pada tingkat satuan pendidikan (sekolah) dilandasi oleh sebuah kurikulum yang berlaku. Saat ini, kurikulum yang diberlakukan di sekolah ialah kurikulum 2013 yang menekankan pada pembelajran saintifik, problem solving dan bertumpu pada pendekatan student center learning. Terdapat beberapa rumpun ilmu yang diaplikasikan dalam beberapa mata pelajaran dalam rangka membelajarkan siswa di sekolah salah satunya ialah matematika. Mata pelajaran matematika sebagai salah satu pelajaran yang berfokus dalam hal meningkatkan kritis siswa terhadap pemecahan permasalahan serta pengembangan teknologi dalam pengimplementasi nyata di kegiatan sehari-hari.

Tujuan pendidikan matematika yang dikemukakan oleh (Wijaya, 2012) menjelaskan bahwa mata pelajaran matematika memiliki empat tujuan diantaranya yaitu tujuan praktis, tujuan kemasyarakatan, tujuan profesional, dan tujuan budaya. Sementara itu, Abdul (Ikhsan \& Rizal, 2014) mengatakan, "Matematika mempunyai sifat abstrak yang terdiri dari fakta, operasi atau relasi, konsep dan prinsip". Sehingga untuk mempelajari matematika diperlukan pemahaman konsep yang baik. Pemahaman konsep berarti memahami ide, gagasan, atau pengertian dari suatu peristiwa. Gagne (Suyono \& Hariyanto, 2016) mengemukakan bahwa konsep merupakan simbol hasil pemikiran. Hal tersebut diperoleh dari hasil membuat penafsiran terhadap fakta, prinsip, prosedur, atau fenomena alam dan hubungan antar fakta. Konsep dalam matematika diartikan sebagai ide abstrak yang memberikan kemampuan pada orang untuk dapat mengklasifikasikan objek-objek atau kejadiankejadian kedalam contoh atau bukan kedalam contoh atau bukan contoh dari suatu objek tertentu.

Pemahaman konsep matematis yang kurang baik akan membuat anak sulit memecahkan masalah. Sejalan dengan masalah yang ditemukan peneliti ialah masih banyak siswa yang kurang memiliki kemampuan dalam menyelesaikan persoalan-persoalan matematika dan kurang memahami serta mengenali konsep yang berkaitan dengan pokok bahasan yang sedang dipelajari. Siswa juga kurang memiliki kemampuan dan ketelitian dalam menyimak atau mengenal sebuah persoalan matematika yang berkaitan dengan pokok bahasan tertentu. 
Berdasarkan hasil survey yang dilakukan oleh Trends in Inter-national Mathematics and Science Study (TIMSS) tahun 2011 (Nia Gardenia, 2016) diketahui bahwa "Indonesia menempati peringkat ke 38 dari 43 negara dalam pembelajaran matematika. Aspek yang dinilai dalam matematika adalah pengetahuan tentang fakta, prosedur, konsep, penerapan pengetahuan dan pemahaman konsep". Hasil survey lainnya yang dilakukan Programme for Internasional Student Assessment (PISA) tahun 2018 (Tohir, 2019) menunjukkan bahwa "Prestasi siswa Indonesia berada untuk kategori matematika pada posisi 73 dari 79 negara yang disurvey”. Skor rata-rata kemampuan matematis siswa Indonesia yaitu 379 di bawah skor rata-rata kemampuan matematis siswa di negara lainnya. Bukti yang menunjukkan masih rendahnya kemampuan pemahaman konsep matematis siswa kelas V SDN Sempu 2 dengan skor rata-rata hasil pretest siswa pada kelas kontrol mendapatkan nilai rata-rata 48,5 dan pada kelas eksperimen mendapatkan skor rata-rata 46,3.

Aspek yang dinilai adalah kemampuan pemahaman konsep, pemecahan masalah, kemampuan penalaran, dan kemampuan komunikasi” (Nia Gardenia, 2016). Dari kedua hasil tersebut terlihat bahwa kemampuan siswa Indonesia dalam bidang matematika khususnya kemampuan pemahaman konsep masih rendah. Adapun menurut Effendi (Gita et al., 2014), "Salah satu penyebab rendahnya pemahaman konsep matematis siswa Indonesia terhadap matematika adalah karena dalam proses pembelajaran matematika, guru umumnya terlalu berkonsentrasi pada latihan penyelesaian soal yang lebih bersifat prosedural dan mekanistik". Selain itu, guru juga mendominasi kelas sepenuhnya, dan materi yang disampaikan pada siswa sudah dalam bentuk final, sehingga siswa hanya menerima begitu saja tanpa banyak mengetahui tentang bagaimana, mengapa dan untuk apa materi tersebut diberikan.

Adapun dalam konteks wilayah Provinsi Banten, jurnal hasil penelitian mengenai identifikasi kemampuan matematika siswa sekolah dasar pada olimpiade OSN bidang matematika prov. Banten menunjukan hasil bahwa presentase kemampuan komunikasi menunjukan angka 55\%, pemecahan masalah 53\%, sedangkan penalaran 10\% (Syamsuri, 2013). Hal ini menunjukan bahwa kemampuan matematika siswa SD di Banten terutama dalam penalaran dan pemecahan masalah masih dikatakan cukup rendah. Serupa dengan hal tersebut, hasil observasi pendahuluan peneliti untuk melihat kemampuan pemahaman konsep matematis siswa yang terjadi di SDN Sempu 2 Kota Serang diperoleh hasil rata-rata nilai pretest siswa yang berjumlah 52 sebesar 48,33.

Oleh karena itu, penting kiranya menyiapkan dengan baik perencanaan pembelajaran. Salah satu pembelajaran yang dapat menunjang kemampuan pemahaman konsep matematis siswa adalah dengan menggunakan bahan ajar yang sesuai dengan karakteristik siswa. Selain metode dan model pembelajaran yang tepat, diperlukan juga alat bantu LKS yang diharapkan dapat memicu minat dan motivasi belajar siswa seperti dengan menggunakan LKS eksploratif berkonteks budaya Banten. Pada umumnya penggunaan LKS sebagai alat bantu bahan ajar pembelajaran di sekolah terkesan monoton dan tidak menggugah minat belajar siswa, dikarenakan tidak terlihat menarik, tidak berwarna, dan 
tidak memiliki ciri khas kedaerahan dalam rangka mentransformasikan nilai-nilai budaya daerah tersebut.

Lembar Kerja Siswa atau LKS digunakan sebagai pemandu kegiatan pembelajaran matematika, sebagai latihan aspek kognitif dan semua aspek lainnya. LKS eksploratif akan mendorong siswa untuk menggali lebih dalam nilai-nilai yang ada di lingkungannya, seperti kebudayaan. Kebudayaan daerah atau budaya lokal khususnya Banten dimana kini terlihat semakin terkikis eksistensinya oleh gempuran globalisasi yang semakin pesat dan masif. Hasil penelitian terdahulu yang dilakukan (Dewayani et al., n.d.), menunjukan bahwa LKS eksploratif mampu mengembangkan kemampuan siswa, menemukan serta memahami suatu konsep dan pengetahuan yang baru. Peningkatan yang ada ditinjau dari hasil $\mathrm{N}$-gain pretest dan posttest sebesar 0,67 dengan kategori sedang. Melalui LKS tersebut juga selain pemahaman konsep matematis siswa yang berkembang, siswa juga diharapkan lebih mengenal kebudayaannya sendiri.

Berdasarkan latar belakang masalah tersebut, peneliti tertarik untuk melakukan penelitian dengan judul "Pengaruh Penggunaan LKS Eksploratif Berkonteks Budaya Banten Terhadap Kemampuan Pemahaman Konsep Matematis Di Sekolah Dasar”. Dengan tujuan penelitian untuk mengetahui apakah pencapaian kemampuan pemahaman konsep matematis siswa yang menggunakan LKS eksploratif berkonteks budaya Banten lebih baik daripada siswa yang menggunakan LKS biasa. Selai itu juga untuk mengetahui respon siswa dalam pembelajaran matematika dengan menggunakan LKS eksploratif berkonteks budaya Banten.

\section{METODE}

Metode yang digunakan dalam penelitian ini adalah metode kuasi eksperimen menggunakan analisis data kuantitaif dengan desain non-equivalent control group design, dalam desain ini terdapat tes awal (pretest), perlakuan yang berbeda, tes akhir (posttest). Populasi dalam penelitian ini adalah seluruh siswa kelas V SDN Sempu 2. Skema desain eksperimennya yang tampak seperti dibawah ini (Ruseffendi, 2005):

\section{Tabel 1.}

Desain Penelitian

\begin{tabular}{|lll|}
\hline $\mathrm{O}_{1}$ & $\mathrm{X}$ & $\mathrm{O}_{2}$ \\
\hline $\mathrm{O}_{3}$ & & $\mathrm{O}_{4}$ \\
\hline
\end{tabular}

Keterangan:

$\mathrm{O}_{1} \quad=$ Tes awal sebelum perlakuan diberikan pada kelompok kelas eksperimen.

$\mathrm{O}_{2} \quad=$ Tes akhir setelah perlakuan diberikan pada kelompok kelas eksperimen.

$\mathrm{O}_{3} \quad=$ Tes awal sebelum perlakuan diberikan pada kelompok kelas kontrol.

$\mathrm{O}_{4} \quad=$ Tes akhir setelah perlakuan diberikan pada kelompok kelas kontrol.

$\mathrm{X}=$ Perlakuan dengan menggunakan LKS Eksploratif berkonteks budaya Banten. 
- - - $\quad$ = Garis ini dimaksudkan kelompok tidak dilakukan secara acak namun menggunakan kelas yang ada.

Teknik pengambilan sampel dalam penelitian ini menggunakan teknik sampel jenuh atau sering disebut total sampling. Sehingga sampel dalam penelitian ini adalah siswa kelas VA dan VB. Penelitian menggunakan instrumen tes untuk mengukur kemampuan pemahaman konsep matematis siswa dan angket respon siswa. Tes tersebut dilakukan dua kali, yaitu pada saat sebelum diberi perlakuan (pretest) dan setelah diberi perlakuan (posttest) dengan jumlah soal sebanyak 5 butir soal uraian yang dibuat berdasarkan indikator pemahaman konsep matematis berbentuk soal cerita mengenai permasalahan volume bangun ruang kubus dan balok. Angket respon siswa berisi pernyataan positif dan negatif dengan pilihan jawaban "Ya" dan " Tidak".

Instrumen tes yang digunakan dalam penelitian ini terlebih dahulu dinilai oleh dosen ahli dalam bidang pendidikan matematika sekolah dasar dan dilakukan uji coba untuk mengetahui tingkat kelayakan soal dengan uji validitas, uji reliabilitas, indeks kesukaran, dan daya pembeda. Secara umum indikator kemampuan pemahaman konsep matematis ada 7 sesuai dengan BNSP namun dalam penilitian ini hanya menggunakan 2 indikator dikarenakan sejalan dengan penelitian Nor Aulia (Mukrimatin et al., 2018) dimana hasil dari penelitian beliau memperoleh 3 indikator terendah dan 2 diantaranya adalah indikator yang peneliti gunakan. Setelahnya dilakukan penyesuaian dengan guru kelas $\mathrm{V}$ yang mana memberikan saran cukup 2 indikator yang dipergunakan dalam penelitian. Persentase terendah Agar instrumen tes yang digunakan untuk penelitian ini valid dan reliabel. Pedoman pemberian skor tes kemampuan pemahaman konsep matematis siswa (Faradisa, 2017), yaitu:

\section{Tabel 2.}

Pedoman Pemberian Skor Tes Kemampuan Pemahaman Konsep Matematis Siswa

\begin{tabular}{|c|c|c|}
\hline Aspek yang dinilai & Skor & Keterangan \\
\hline \multirow{4}{*}{$\begin{array}{l}\text { Menggunakan, memanfaatkan dan } \\
\text { memilih prosedur atau operasi } \\
\text { tertentu }\end{array}$} & 3 & $\begin{array}{l}\text { Dapat menggunakan dan memilih prosedur operasi } \\
\text { tertentu dengan benar }\end{array}$ \\
\hline & 2 & $\begin{array}{l}\text { Dapat menggunakan dan memilih prosedur atau } \\
\text { operasi tertentu tetapi masih melakukan kesalahan }\end{array}$ \\
\hline & 1 & $\begin{array}{l}\text { Ada jawaban tetapi tidak sesuai dengan prosedur } \\
\text { operasi tertentu }\end{array}$ \\
\hline & 0 & Tidak ada jawabn untuk menjawab soal \\
\hline \multirow[t]{4}{*}{$\begin{array}{l}\text { Mengaplikasikan konsep atau } \\
\text { alogaritma pada pemecahan masalah }\end{array}$} & 3 & $\begin{array}{l}\text { Menggunakan alogaritma dalam pemecahan } \\
\text { masalah dengan tepat. }\end{array}$ \\
\hline & 2 & $\begin{array}{l}\text { Menggunakan alogaritma dalam pemecahan } \\
\text { masalah tetapi salah }\end{array}$ \\
\hline & 1 & $\begin{array}{l}\text { Ada jawaban tetapi tidak sesuai dengan alogaritma } \\
\text { pemecahan masalah }\end{array}$ \\
\hline & 0 & Tidak ada jawabn untuk menjawab soal \\
\hline
\end{tabular}

Data hasil tes awal (pretest) dan tes akhir (posttest) diolah dan dianalisis sesuai dengan rumusan masalah yang telah dibuat sebelumnya. Dengan menggunakan statistik deskriptif dan statistik inferensial. 


\section{HASIL}

Penelitian dilaksanakan di SD Negeri Sempu 2 tahun ajaran 2019/2020. Penelitian ini dilakukan sejak tanggal 16 Februari 2020 sampai dengan tanggal 15 Maret 2020 pada siswa kelas VA sebagai kelas kontrol dan siswa kelas VB sebagai kelas eksperimen. Kedua kelas diberi perlakuan yang berbeda dari segi LKS, kelas kontrol diberi perlakuan dengan LKS yang didapat siswa dari sekolah sedangkan kelas eksperimen diberi perlakuan dengan menggunakan LKS eskploratif berkonteks budaya Banten. Berikut cuplikan LKS eksploratif berkonteks buadaya Banten:

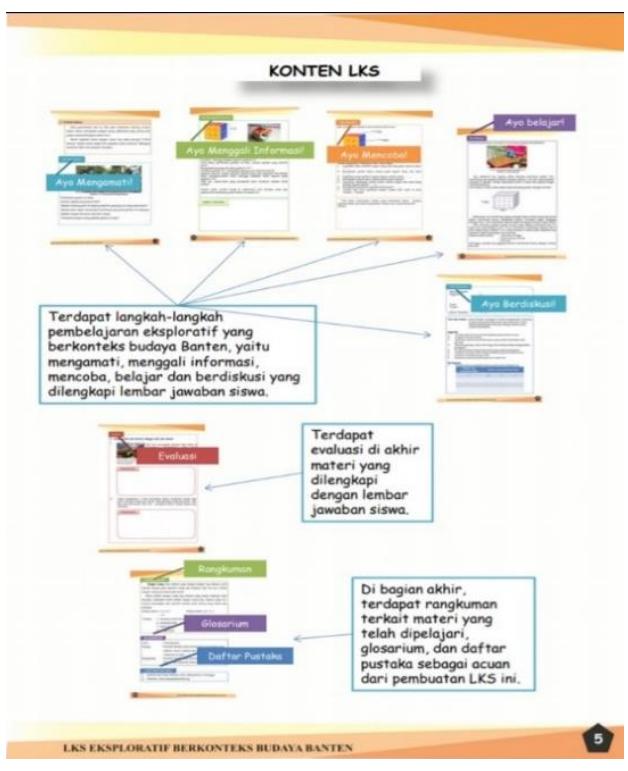

Gambar 1. Cuplikan LKS Eksploratif Berkonteks Budaya Banten

Pengambilan pretest dilakukan untuk mengetahui kemampuan awal siswa kedua kelas tersebut, sebelum diberikan perlakuan yang berbeda. Hasil pretest tersebut sebagai berikut:

Tabel 3.

Rekapulasi Data Pretest Kemampuan Pemahaman Konsep Matematis Siswa

\begin{tabular}{|c|l|c|c|}
\hline \multirow{2}{*}{ No } & \multirow{2}{*}{ Statistik } & \multicolumn{2}{|c|}{ Hasil Pretest } \\
\cline { 3 - 4 } & & Eksperimen & Kontrol \\
\hline 1 & Banyak Siswa (n) & $\mathbf{2 6}$ & $\mathbf{2 6}$ \\
\hline 2 & Nilai Maksimum & $\mathbf{8 7}$ & $\mathbf{8 7}$ \\
\hline 3 & Nilai Minimum & $\mathbf{7}$ & $\mathbf{7}$ \\
\hline 4 & Nilai Rata-Rata $(\bar{x})$ & $\mathbf{4 6 , 3}$ & $\mathbf{4 8 , 5}$ \\
\hline 5 & Simpangan Baku $(\mathrm{S})$ & $\mathbf{5 0 0 , 8 6}$ & $\mathbf{5 0 5 , 6 8}$ \\
\hline 6 & Varians $\left(S^{2}\right)$ & $\mathbf{2 2 , 3 8}$ & $\mathbf{2 2 , 4 9}$ \\
\hline
\end{tabular}

Adapun Posttest dilakukan untuk mengetahui kemampuan siswa kedua kelas tersebut setelah diberikan perlakuan yang berbeda. Serta untuk mengetahui apakah kemampuan pemahaman konsep matematis siswa kelas eksperimen lebih baik jika dibandingkan dengan kelas kontrol setelah di berikan perlakuan. Berikut hasil posttest tersebut. 
Pengaruh Penggunaan Lks Eksploratif Berkonteks Budaya Banten Terhadap Kemampuan Pemahaman Konsep Matematis di Sekolah Dasar, Melia Livita Elvara, Sukirwan, Aan Subhan Pamungkas

Tabel 4.

Rekapulasi Data Posttest Kemampuan Pemahaman Konsep Matematis Siswa

\begin{tabular}{|c|l|c|c|}
\hline \multirow{2}{*}{ No } & \multirow{2}{*}{ Statistik } & \multicolumn{2}{|c|}{ Hasil Pretest } \\
\cline { 3 - 4 } & & Eksperimen & Kontrol \\
\hline 1 & Banyak Siswa $(\mathrm{n})$ & $\mathbf{2 5}$ & $\mathbf{2 5}$ \\
\hline 2 & Nilai Maksimum & $\mathbf{1 0 0}$ & $\mathbf{1 0 0}$ \\
\hline 3 & Nilai Minimum & $\mathbf{6 0}$ & $\mathbf{5 3}$ \\
\hline 4 & Nilai Rata-Rata $(\bar{x})$ & $\mathbf{8 7 , 6}$ & $\mathbf{7 6 , 7}$ \\
\hline 5 & Simpangan Baku $(\mathrm{S})$ & $\mathbf{8 , 8 4}$ & $\mathbf{1 1 , 3 4}$ \\
\hline 6 & Varians $\left(S^{2}\right)$ & $\mathbf{7 8 , 7 0 3}$ & $\mathbf{1 2 8 , 6 4}$ \\
\hline
\end{tabular}

Hasil rekapitulasi data posttest di atas menyatakan bahwa kelas eksperimen memperoleh nilai ratarata sebesar 87,6 lebih tinggi dibandingkan kelas kontrol sebesar 76,7. Adapun diagram rekapitulasi kemampuan pemecahan masalah matematis pretest dan posttest siswa kelas eksperimen dan kelas kontrol yaitu sebagai berikut:

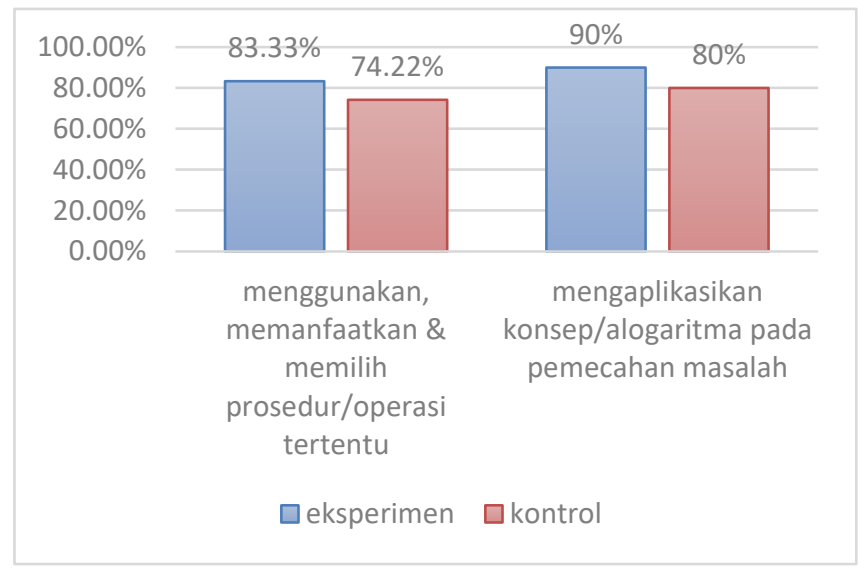

Gambar 2. Diagram Rekapitulasi Data Pretest dan Postest

Guna menganalisis setiap indikator kemampuan pemahaman konsep matematis siswa di kelas eksperimen dan kelas kontrol yaitu dengan menghitung persentase skor yang diperoleh tiap indikator ditinjau dari keseluruhan siswa agar dapat dibandingkan perolehan antara kedua kelas tersebut. Hasil analisis setiap indikator di sajikan dalam diagram berikut.

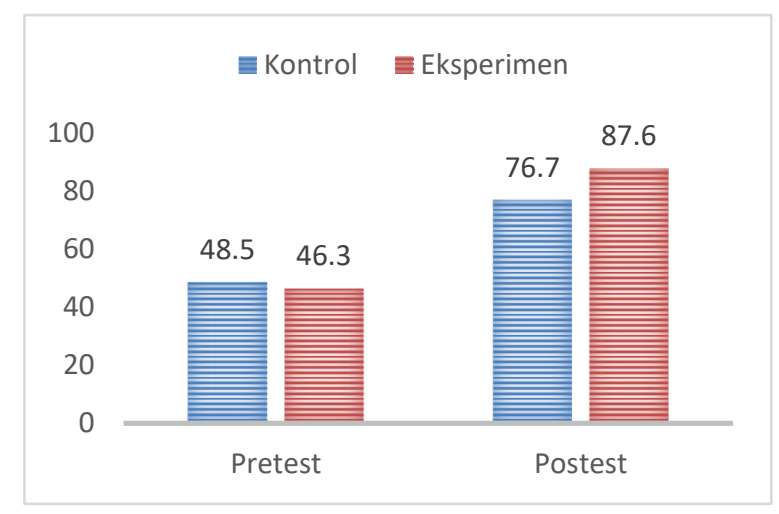

Gambar 2. Diagram Persentase Tiap Indikator Kemampuan Pemahaman Konsep Matematis Siswa Posttest dan Pretest 
Berdasarkan diagram secara umum indikator pemahaman konsep matematis siswa kelas eksperimen lebih tinggi dibandingkan dengan kelas kontrol dari semua indikator. Penyebab perbedaan rata-rata nilai pemahaman konsep antara kelas eksperimen dan kelas kontrol yaitu karena perbedaan penggunaan LKS pada masing-masing kelas. Pada kelas eksperimen LKS yang digunakan ialah LKS eksploratif berkonteks budaya Banten, oleh karenanya hal itu berimplikasi positif terhadap peningkatan keaktifan dan motivasi belajar siswa dalam memahami konsep matematis yang diajarkan dalam pembelajaran.

Kedua kelompok eksperimen dan kelompok kontrol berdistribusi normal dan homogen. Selanjutnya di uji kesamaan dua rata-rata dengan menggunakan uji-t dua pihak dengan rumus polled varians, $\mathrm{a}=0,05$ dan $\mathrm{dk}=\mathrm{n} 1+\mathrm{n} 2-2$ dengan menunjukan hasil berikut.

\section{Tabel 5.}

Hasil Beda Dua Rata-Rata Pretest

\begin{tabular}{|c|c|c|}
\hline Jenis Uji & Statistik & Simpulan \\
\hline \multirow{2}{*}{ Uji-t } & $t_{\text {hitung }}=0,37$ & \multirow{2}{*}{ Terdapat perbedaan } \\
\cline { 2 - 2 } & $t_{\text {tabel }}=2,60$ & \\
\hline
\end{tabular}

Berdasarkan tabel 4 tersebut, uji beda dua rata-rata pada pretest yang ditunjukkan pada tabel diatas bahwa $0,37<2,60$ sehingga dapat disimpulkan bahwa kelas eksperimen tidak lebih baik daripada kelas kontrol. Sedangkan;

\section{Tabel 6.}

\section{Hasil Beda Dua Rata-Rata Postest}

\begin{tabular}{|c|c|c|}
\hline Jenis Uji & Statistik & Simpulan \\
\hline \multirow{2}{*}{ Uji-t } & $t_{\text {hitung }}=3,79$ & \multirow{2}{*}{ Ho Ditolak atau Terdapat Perbedaan } \\
\cline { 2 - 2 } & $t_{\text {tabel }}=2,50$ & \\
\hline
\end{tabular}

Berdasarkan tabel 5 tersebut, uji beda dua rata-rata pada posttest didapat bahwa t-hitung=3,79 dan t-tabel $=2,5$ maka 3,7906 > 2,5 sehingga dapat disimpulkan bahwa kelas kontrol dan kelas eksperimen memiliki kemampuan yang berbeda setelah diberikan perlakuan.

\section{Tabel 6.}

Hasil Uji Satu Pihak Posttest

\begin{tabular}{|l|c|c|}
\hline Jenis Uji & Statistik & Simpulan \\
\hline \multirow{2}{*}{ Uji-t } & $t_{\text {hitung }}=3,79$ & \multirow{2}{*}{ Kelas eksperimen lebih baik dibandingan kelas kontrol } \\
\cline { 2 - 2 } & $t_{\text {tabel }}=2,50$ & \\
\hline
\end{tabular}

Berdasarkan tabel 6 tersebut, didapat bahwa t_hitung >t_tabel maka 3,79>2,5 sehingga dapat disimpulkan bahwa kemampuan pemahaman konsep matematis siswa kelas eksperimen yang menggunakan LKS eksploratif lebih baik daripada siswa kelas kontrol yang menggunakan LKS biasa. 
Pengaruh Penggunaan Lks Eksploratif Berkonteks Budaya Banten Terhadap Kemampuan Pemahaman Konsep Matematis di Sekolah Dasar, Melia Livita Elvara, Sukirwan, Aan Subhan Pamungkas

\section{Tabel 7.}

Persentase Tiap Indikator Data Angket Respon Siswa

\begin{tabular}{|c|l|c|c|c|}
\hline No & \multicolumn{1}{|c|}{ Indikator } & Skor & $\mathbf{( \% )}$ & Keterangan \\
\hline 1 & $\begin{array}{l}\text { Motivasi Belajar Siswa Bertambah Terhadap Penggunaan } \\
\text { LKS Eksploratif Berkonteks Budaya Banten }\end{array}$ & 163 & 93,1 & Sangat Baik \\
\hline 2 & $\begin{array}{l}\text { Penggunaan LKS Eksploratif Berkonteks Budaya Banten } \\
\text { Mudah Difahami Dan Dapat Dirasakan Manfaatnya Dalam } \\
\text { Kehidupan Sehari-Hari }\end{array}$ & 117 & 93,6 & Sangat Baik \\
\hline 3 & $\begin{array}{l}\text { Minat Dan Ketertarikan Belajar Siswa Tumbuh Dengan } \\
\text { Menggunakan LKS Eksploratif Berkonteks Budaya Banten }\end{array}$ & 186 & 93 & Sangat Baik \\
\hline
\end{tabular}

Berdasarkan hasil perhitungan tersebut, diperoleh total skor mentah 466 dan skor ideal 500, sehingga nilai persentase akhir yang diberi siswa terhadap LKS eksploratif berkonteks budaya Banten sebesar 93,2\%. Maka dari rentang $80<\mathrm{NP} \leq 100 \%$, hal ini menunjukan ke dalam kriteria responden sangat baik. Penggunaan LKS eksploratif berkonteks budaya Banten dapat meningkatkan kemampuan pemahaman konsep matematis siswa menjadi lebih baik. Hal ini didasarkan pada hasil perhitungan data, diperoleh nilai rata-rata pretest kelas kontrol yang lebih baik dari pada kelas ekperimen atau dapat dikatakan kedua kelompok sampel memiliki kemampuan pemahaman konsep matematis yang berbeda pada saat sebelum dilakukan treatment.

Namun, setelah dilakukan perlakuan di masing-masing kelas yaitu pembelajaran menggunakan LKS ekploratif berkonteks budaya Banten pada kelas ekperimen dan pembelajaran menggunakan LKS yang didapat dari sekolah pada kelas kontrol diperoleh nilai rata-rata pada kemampuan pemahaman konsep matematis siswa dimana mendapatkan perbedaan yang cukup jauh yaitu kelas ekperimen 87,6 sedangkan kelas kontrol sebesar 76,7 hal ini bisa terjadi karena terdapat beberapa faktor berbeda perlakuan yang diberikan pada masing-masing sampel.

Sejalan dengan penelitian yang telah dilakukan oleh (Masitoh \& Prabawanto, 2016) dengan populasi seluruh siswa kelas V SDN yang berada di Kecamatan Dermaga Kabupaten Bogor, memperoleh perbedaan dari hasil rata-rata posttest kemampuan pemahaman konsep matematika diketahui siswa kelas eksperimen yang melakukan pembelajaran eksploratif lebih tinggi daripada siswa kelas kontrol yang melakukan pembelajaran langsung. Dengan hasil nilai rata-rata N-gain pemahaman konsep matematika pada kelas eksperimen sebesar 0,63 sedangakan pada kelas kontrol sebesar 0,27. Kemudian hasil analisis tiap indikator kemampuan pemahaman konsep matematis dibahas dalam beberapa indikator berikut;

a) Menggunakan, memanfaatkan dan memilih prosedur atau operasi tertentu.

Indikator kemampuan pemahaman konsep matematis yang berupa menggunakan, memanfaatkan dan memilih prosedur atau operasi tertentu menunjukan presentase pada kelas eksperimen sebesar 83,33\% dengan kategori sangat baik sedangkan kelas kontrol sebesar 74,22\% dengan kategori baik. pencapaian pada indikator menunjukkan bahwa indikator kemampuan pemahaman konsep matematis yang berupa menggunakan, memanfaatkan dan memilih prosedur atau 
operasi tertentu lebih tinggi ketika menggunakan LKS eksploratif berkonteks budaya Banten dibandingkan dengan menggunakan LKS yang didapat siswa dari sekolah.

b) Mengaplikasikan konsep atau alogaritma pada pemecahan masalah Indikator kemampuan pemahaman

Konsep matematis yang berupa mengaplikasikan konsep atau alogaritma pada pemecahan menunjukan persentase pada kelas eksperimen sebesar 90\% dengan kategori sangat baik sedangkan kelas kontrol sebesar $80 \%$ dengan kategori baik. Pencapaian pada indikator menunjukkan bahwa indikator kemampuan pemahaman konsep matematis yang berupa mengaplikasikan konsep atau alogaritma pada pemecahan masalah lebih tinggi ketika menggunakan LKS eksploratif berkonteks budaya Banten dibandingkan dengan menggunakan LKS yang didapat siswa dari sekolah.

Selanjutnya dilakukan analisis tiap indikator angket respon siswa pada kelas eksperimen dengan hasil diketahui sebagai berikut.

Motivasi Belajar Siswa Bertambah Terhadap Penggunaan LKS Eksploratif Berkonteks Budaya Banten

Indikator angket respon siswa yang pertama ialah motivasi belajar siswa bertambah terhadap penggunaan LKS eksploratif berkonteks budaya Banten. Adapun persentase hasil indikator ini sebesar 93,1\% dengan kategori sangat baik. Pencapaian pada indikator ini menunjukkan bahwa motivasi belajar siswa bertambah pada saat kegiatan pembelajaran berlangsung dengan menggunakan LKS eksploratif berkonteks budaya Banten. Hal ini karena warna dan gambar yang terdapat pada LKS membuat siswa semangat belajar, sampul depan LKS juga membuat rasa ingin tahu siswa meningkat untuk melanjutkan kegiatan pembelajaran, permasalahan atau kasus-kasus yang terdapat pada LKS mampu meningkatkan keaktifan siswa dalam proses pembelajaran, dan siswa pun merasa senang saat belajar matematika menggunakan LKS eksploratif berkonteks budaya Banten.

Penggunaan LKS Eksploratif Berkonteks Budaya Banten Mudah Difahami dan dapat Dirasakan Manfaatnya dalam Kehidupan Sehari-hari

Penggunaan LKS eksploratif ketika proses pembelajaran mudah difahami dan dapat dirasakan manfaatnya dalam kehidupan sehari-hari hal ini dibuktikan dengan hasil persentase pada indikator sebesar 93,6\% dengan kategori sangat baik. Hasil persentase yang sangat baik dikarenakan menurut siswa LKS eksploratif sangat membantu dan membuat siswa mudah memahami materi yang dipelajari serta dapat menambah pengetahuan. Siswa juga dapat menghubungkan isi dalam LKS dengan hal-hal yang mereka lihat, lakukan, dan pikirkan dalam kehidupan sehari-hari.

Minat Dan Ketertarikan Belajar Siswa Tumbuh Dengan Menggunakan LKS Eksploratif Berkonteks Budaya Banten

Pada indikator minat dan ketertarikan belajar siswa tumbuh dengan menggunakan LKS menunjukan hasil persentase pada indikator ini yaitu 93\% dimana berkategori sangat baik. Hal ini dikarenakan pembelajaran matematika menggunakan LKS eksploratif sangat menarik dan 
menyenangkan, siswa pun berharap agar pembelajaran matematika di semua materi menggunakan LKS eksploratif berkontesk budaya Banten.

Adapun kegiatan pembelajaran yang dilakukan memuat beberapa tahapan, mulai dari ayo mengamati, ayo menggali informasi, ayo mencoba, ayo belajar, dan yang terakhir ayo berdiskusi. Setelah tahapan tersebut selesai, siswa diberikan reward untuk kelompok yang berpartisipasi secara aktif dalam pembelajaran tersebut, dengan harapan sebagai acuan motivasi untuk merangsang kelompok lainnya agar lebih meningkatkan keaktifannya. Ketika kegiatan pembelajaran berlangsung dari pembuka sampai penutup, sebagian besar siswa mengikuti setiap langkah pembelajaran dengan tertib, walaupun pada saat membagi kelompok suasana kelas kurang tenang karena siswa harus mengatur posisi kursi dan mejanya senyaman mungkin agar mempermudah dan nyaman dalam berdiskusi.

Pada saat kegiatan inti pembelajaran berlangsung siswa berpartisipasi dalam menyelesaikan setiap tugas yang diberikan peneliti karena dalam penelitian ini siswa dituntut aktif dan mampu memahami setiap konsep dan permasalahan yang terdapat pada LKS eksploratif sehingga dapat dikatakan pembelajaran dengan menggunakan LKS eksploratif berkonteks budaya Banten dapat memberikan pengalaman belajar bemakna dan membantu siswa dalam mamahami konsep matematis dalam materi volume bangun ruang kubus dan balok.

Hal ini dibuktikan dengan hasil rata-rata nilai pretest dan posttest kelas eksperimen dan kelas kontrol, dimana nilai rata-rata pretest kelas kontrol lebih baik dibandingkan dengan nilai rata-rata pretset kelas eksperimen yaitu 48,6 > 46,3 sedangkan rata-rata postets atau tes akhir jauh lebih baik kelas eksperimen jika dibandingkan dengan hasil postest kelas kontrol yaitu nilai rata- rata kelas kontrol 76,7 dan nilai rata-rata kelas eksperimen 87,6. Sejalan dengan data tersebut, Dewayani (2016) menjelaskan bahwa LKS ekploratif dianggap mampu untuk mengembangkan kemampuan siswa untuk menemukan serta memahami suatu konsep atau pengetahuan yang baru. Berdasarkan pembahasan penelitian, maka hipotesa dapat diterima yakni penggunaaan LKS eksploratif berkonteks budaya Banten berlangsung mampu memberikan pengaruh/perbedaan terhadap kemampuan pemahaman konsep matematis siswa SD.

\section{KESIMPULAN}

Berdasarkan tujuan penulisan yang telah dirumuskan, maka dapat diambil kesimpulan sebagai berikut.

1. Kemampuan pemahaman konsep matematis siswa lebih baik menggunakan LKS eksploratif berkonteks budaya banten hal ini dapat dibuktikan melalui perolehan nilai rata-rata posttest pada kelas kontrol diperoleh nilai rata-rata pada kemampuan pemahaman konsep matematis siswa dimana mendapatkan perbedaan yang cukup jauh yaitu kelas ekperimen 87,6 sedangkan kelas kontrol sebesar 76,7. 
2. Respon siswa setelah menggunakan LKS eksploratif berkonteks budaya Banten dinilai positif. Hal ini dapat dibuktikan dengan hasil analisis indikator meliputi; a) motivasi belajar siswa bertambah terhadap penggunaan LKS eksploratif berkonteks budaya Banten yang menunjukan persentase hasil indikator ini sebesar 93,1\% dengan kategori sangat baik; b) penggunaan LKS eksploratif ketika proses pembelajaran mudah difahami dan dapat dirasakan manfaatnya dalam kehidupan sehari-hari hal ini dibuktikan dengan hasil persentase pada indikator sebesar 93,6\% dengan kategori sangat baik; c) minat dan ketertarikan belajar siswa tumbuh dengan menggunakan LKS Eksploratif Berkonteks Budaya Banten hal ini ditunjukan pada hasil persentase yaitu $93 \%$ yang berarti berkategori sangat baik.

Adapun terdapat beberapa saran dapat disampaikan dalam penelitian ini diantaranya; penggunaan LKS eksploratif konteks budaya Banten perlu dikembangkan lagi untuk dapat digunakan secara relevan pada kemampuan peserta didik di SD lebih luas lagi selain pemahaman matematis siswa SD. Pengembangan penelitian mengenai penggunaan LKS eksploratif perlu dikembangkan lebih luas pada jenjang yang lebih luas lagi, mengingat keterbatasan peneliti dalam melakukan penelitian tersebut dikarenakan banyak hal, salah satunya ialah kesulitan mengambil data secara komperhensif dikarenakan kondisi penelitian yang tidak memungkinkan.

\section{DAFTAR PUSTAKA}

Dewayani, A., Kadarisman, N., Discovery, P., \& Kritis, K. B. (n.d.). Menggunakan Pendekatan Discovery Untuk Meningkatkan the Development of Explorative Worksheet for Students Using Discovery. 183-190.

Faradisa, I. (2017). Pengaruh Model Pembelajaran Kooperatif Make A Match Terhadap Pemahaman Konsep Matematika Siswa Kelas VIII SMP Negeri 1 SIMAN Ponorogo. Ponorogo: Universitas Muhammadiyah Ponorogo.

Gita, P., Dantes, N., \& Sariyasa. (2014). Pengaruh Model Reciprocal Teaching Terhadap Pemahaman Konsep dan Motivasi Belajar Matematika Siswa kelas V SD. E-Journal Program Pascsarjana Universitas Pendidikan Ganesha, 4, 1-10.

Ikhsan, M., \& Rizal, S. (2014). Meningkatkan Kemampuan Pemahaman Dan Komunikasi Matematis Siswa Sekolah Menengah Atas Melalui Model Pembelajaran Generatif. Didaktik Matematika, 1(2), 75-84. https://doi.org/10.24815/jdm.v1i2.2070

Masitoh, I., \& Prabawanto, S. (2016). Peningkatan Pemahaman Konsep Matematika dan Kemampuan Berfikir Kritis Matematis Siswa Kelas V Sekolah Dasar Melalui Pembelajaran Eksloratif. EduHumaniora | Jurnal Pendidikan Dasar Kampus Cibiru, 7(2), 186. https://doi.org/10.17509/eh.v7i2.2709

Mukrimatin, N. A., Murtono, M., \& Wanabuliandari, S. (2018). Pemahaman Konsep Matematika Siswa Kelas V SD Negeri Rau Kedung Jepara Pada Materi Perkalian Pecahan. ANARGYA: Jurnal Ilmiah Pendidikan Matematika, 1(1), 67-71. 
Pengaruh Penggunaan Lks Eksploratif Berkonteks Budaya Banten Terhadap Kemampuan Pemahaman Konsep Matematis di Sekolah Dasar, Melia Livita Elvara, Sukirwan, Aan Subhan Pamungkas

https://doi.org/10.24176/anargya.v1i1.2277

Nia Gardenia. (2016). Peningkatan Kemampuan Pemahaman Dan Komunikasi Matematis Siswa SMP Melalui Pembelajaran Kontruktivisme Model Needham. Jurnal Formatif, 6(2), 110-118.

Ruseffendi. (2005). Dasar-Dasar Penelitian Pendidikan dan Bidang Non Eksakta Lainnya. Bandung: Tarsito.

Suyono, \& Hariyanto. (2016). Belajar dan Pembelajaran. Bandung: Rosdakarya.

Syamsuri. (2013). Identifikasi Kemampuan Matematika Siswa Sekolah Dasar pada Olimpiade Sains Nasional (OSN) Bidang Matematika Tingkat Provinsi Banten. Jurnal Penelitian Dan Pembelajaran Matematika (JPPM), 6.

Titarahardja, U., \& Sulo, L. (2013). Pengantar Pendidikan. Jakarta: Rineka Cipta.

Tohir, M. (2019). Hasil PISA Indonesia Tahun 2018 Turun Dibanding Tahun 2015. In https://matematohir.wordpress.com/2019/12/03/hasil-pisa-indonesia-tahun-2018-turundibanding- tahun-2015. Dilaman pada 8 Mei 2020.

Wijaya, A. (2012). Pendidikan Matematika Realistik, Suatu Alternatif Pendekatan Pembelajaran Matematika. Yogyakarta: Graha Ilmu. 